\title{
A Production Method of Electrically Conductive Glasses by High School Classes and a Practice of the Dye-Sensitized Solar Cells Experiment
}

\author{
Yasufumi KAWAmuRA*1, Atsushi WatanaBe*2, Yu MATSUmoto*1, and Shohei YoKoyama*2 \\ (Received March 28, 2013)
}

\section{高校生が授業内でできる電気伝導性ガラス製作とそれを用いた色素増感太陽電池実験の授業実践 川村康文*1，渡部 温*2，松本 悠*1，横山昇平*2}

Solar cells are getting familiar to science teachers as teaching materials in a new course of study which started in 2011. Among many types of solar cells, researchers are paying attention to the dye-sensitized solar cells experiment because students can produce by themselves. After the Great East Japan Earthquake, we cannot teach the experiment classes to produce the dye-sensitized solar cells because we cannot obtain the electrically conductive glasses. Therefore, we developed a production method of the electrically conductive glasses which high school students can perform, and practiced the dye-sensitized solar cells experiment with them. We report on the results.

太陽光電池教材は，2011年より改訂された学習指導要領におけるエネルギー環境教育分野を指導するうえ で, 多くの教員が利用している教材であるといえる。太陽電池には多くの種類があるが，特に学習者が興味・ 関心をひかれるのは生徒自信が作製可能な色素増感太陽電池である。

しかし，2011年 3 月 11 日に起こった東日本大地震により電気伝導性ガラスの生産工場が被災し, 電気伝導 性ガラスの入手が不可能となり, 教員が色素増感太陽電池の指導が不可能となった。そこで, 高校生が授業時 間中に作製可能な電気伝導性ガラスの作製方法を開発し、色素増感太陽電池教材の一環として実践を行い, そ の結果をまとめた。

\section{Key Words}

Electrically conductive glasses, Dye-sensitized solar cells, The Great East Japan Earthquake

1. はじめに

高等学校における新学習指導要領が平成25年度より全面実 施され，それより先に学習指導要領の改訂があった小中学校 に続いて全ての校種において新学習指導要領に沿った学習が スタートすることとなる（高等学校の数学と理科は平成 24 年 度より先行実施されている)。理科の新学習指導要領では, 中 学校において新単元「科学技術と人間」, 高等学校において新 教科「科学と人間生活」が設置され,「科学」と「人間」の関 わりを学習する機会が増加している。それらの学習単元や科 目に扮ける「エネルギー変換」や「エネルギー効率」につい ての学習では太陽電池を用いた授業を行うことが推奨されて いる ${ }^{1)}$ 。実際に, 平成 24 年度先行実施, 物理基礎の教科書に

\footnotetext{
* 1 Tokyo University of Science

1-3 Kagurazaka, Shinjuku-ku, Tokyo 162-8601, Japan

* 2 Tokyo University of Science

1-3 Kagurazaka, Shinjuku-ku, Tokyo 162-8601, Japan
}

おける課題研究のページにて色素増感太陽電池が掲載されて いることからも, エネルギー学習において, 太陽電池は教材 としての学習効果が期待されているといえる2)。色素増感太陽 電池は実際に理科室で生徒に手作りさせることができ, さら にエネルギー環境教育教材としての学習効果が高いことも既 に報告されているため, SSH(スーパーサイエンスハイスクー ル)やSPP(サイエンスパートナーシッププロジェクト), 様々 な講習や研修などにおいて活用されている314)。川村らは, こ れまでも, 色素増感太陽電池の実験教材の開発を授業実践を 通して行ってきた5) 7)。ところが, 東日本大震災の影響によ り色素増感太陽電池に必要な電気伝導性ガラスの入手が, 一 時期, 困難となった。そのため, 授業実践や研究開発を行う

\footnotetext{
* 1 東京理科大学理学部第一部 ₹ 162-8601 東京都新宿区神楽坂 1-3

*2 東京理科大学科学教育研究科科学教育専攻 干 162-8601 東京都新宿区神楽坂 1-3
} 
のが難しい状況となった。またもともと，色素増感太陽電池 が，高等学校で生徒実験としてもっと広く実施されるには，購 入価格が高価である電伝導性ガラスを，生徒が自作すること ができるようになる必要性を感じていた。このたび，震災に より，電気伝導性ガラスの入手が困難となったことをきっか けに, 高等学校の授業時間内に, 高校生が電気伝導性ガラス を作って，そのガラスを用いて色素増感太陽電池実験ができ る実験教材の開発を, 研究の目標とした。授業実践において, 高校生全員が実験に成功したので報告をする。

\section{2. 色素増感太陽電池とは}

現在，太陽電池の中で最もよく利用されているシリコン系 太陽電池は，製造のために高度なクリーンルームの建設が必 要であり, さらに, シリコンは PC・携帯電話の普及に伴い, それらのCPUなどの材料としての需要が増大しており,太陽 電池向け材料供給との競合が懸念される。また，製造段階に て有害な物質も使用されているため，廃棄の段階で大量の産 業廃衰物が出ることが懸念され, 太陽電池が, 高校生の学習 教材として，一概に環境に優しいとはいい難い現状がある。一 方, 色素増感太陽電池は, 変換効率ではシリコン系に及ばな いが，比較的小規模の施設での製造が可能で，低コストで製 造でき, 用いる材料が環境への負荷が少ないという特徵があ るため, 次なる太陽電池として高い注目を集め, 高校生が夢 をもてるものとなっている。

·色素増感太陽電池の発電原理

色素増感太陽電池は，スイスのグレッツェルによって開発 されたものである。主な材料は，電気伝導性ガラス，二酸化 チタン, 色素, 電解液である。色素増感太陽電池の発電原理 は以下の通りである（図 1 ）。

（1）二酸化チタンを焼き付けた電気伝導性ガラス電極側に光 を照射する

（2）色素が可視光を吸収し，電子とホールが発生する

(3) 電子は速やかに半導体の二酸化チタン多孔質膜へ注入さ れ，ガラス電極に伝わる

（4）さらに，電子は集電端より取り出され，負荷を動かし，対

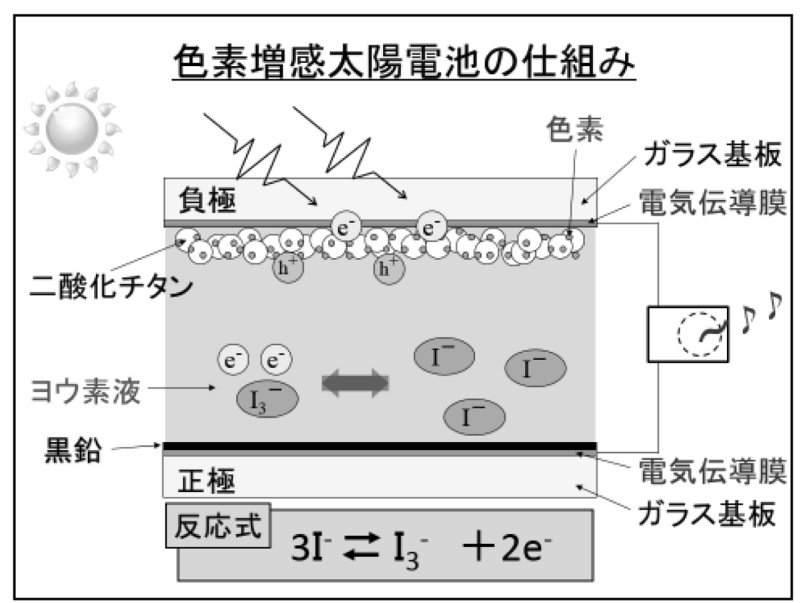

図 1 色素増感太陽電池原理図
極へと移動する

（5）対極上の電子は電解液中の三ヨウ化物イオン $\left(\mathrm{I}_{3}{ }^{-}\right)$を還 元し，ヨウ化物イオン $\left(\mathrm{I}^{-}\right)$になる

$\mathrm{I}_{3}^{-}+2 \mathrm{e}^{-} \rightarrow 3 \mathrm{I}^{-}$

（6）還元されたヨウ化物イオンは色素上に取り残されたホー ルと結合し，酸化されて再び三ヨウ化物イオンとなる $3 \mathrm{I}^{-} \rightarrow \mathrm{I}_{3}^{-}+2 \mathrm{e}$

（7）上記 $(1) 〜(6)$ を繰り返して電気が流れる

動作原理がシリコン系太陽電池のように光励起で発生した 電子とホールをそのまま直接取り出して電流とするのではな く, 電解質溶液の酸化·還元を伴うことから, “光合成の水素 伝達回路”に例えて “光合成模倣型光電池”といった呼ばれ 方をされることもある。

\section{3. 開発した電気伝導性ガラス製作実験}

電気伝導性ガラスの製造工場はもともと東北地方に多く あったため，震災後は，電気伝導性ガラスの入手が難しくな り，授業前に電気伝導性ガラスの購入を依頼しても授業には 間に合わない可能性があるという状況に陥ってしまっていた。 そこでその状況を解決すべく, 電気伝導性ガラス製作実験の 開発を行った。本研究では，授業で高校生が色素増感太陽電 池実験を行うのに，授業中に電気伝導性ガラス製作から始め ても，色素増感太陽電池の発電確認までが実施できるような 教材の研究開発を行った。電気伝導性ガラス製作の方法につ いては，大学研究室では一般的なスパッ夕法を利用すること も考えたが，高等学校の授業での実施は予算の面から考えて も困難であると考えた。そこで，高校生にも製作可能な電気 伝導性ガラスを作る方法について検討した結果，スプレー法 を選択することとした。スプレー法については様々な方法が 知られるが, 我々は, 澤田の方法 ${ }^{8)}$ を選択し, これを高校生 が実際に授業のなかでできる実験方法にすることを考えた。 澤田の方法において，実験の成功のためのポイントや実験上 の安全性について，直接，澤田氏に教授を受け，それをもとに 高校生でもできる方法へと改善した 、その方法を以下に示す。 まず，電気伝導性ガラス製作実験に必要な材料を示す。

·100円ショップのフォトフレームのガラス (ガラスの厚み が1.5 mmのものを使用した)，・塩化スズ（II）( $\mathrm{SnCl}_{2}$ ，和 光純薬工業 $($ 株 $))$, ・エタノール $\left(\mathrm{C}_{2} \mathrm{H}_{6} \mathrm{O}\right.$, 純度 $99.5 \%$, 関 東化学(株))，・ガスコンロ，・ガスボンベ，・鍋焼きうど ん用容器 (アルミ製)，・100円ショップのアルコール用ア トマイザー，・スターラー，・ガラスカッター，・キムワ イプ 次に製作手順を示す。

なお以下の手順は，すべてドラフトの中で実施した。また， 高校の化学実験室にはほとんどの場合ドラフトは設置されて いる。

1) 濃度 $0.158 \mathrm{~mol} / \mathrm{L}$ となるよう, エタノール $100 \mathrm{~mL}$ に対し, 塩化スズを $3.00 \mathrm{~g}$ 溶かし，スターラーで約 5 分間擋拌した (スターラーが無ければガラス棒で全て溶けるまで攪拌する 方法でも可)。 
2) フォトフレームのガラスを $2 \mathrm{~cm} \times 2 \mathrm{~cm}$ のイズにガラス カッターで切り出し, エタノールを染み込ませたキムワイ プで表面の污れをとった。

3）ドラフト内にガスコンロを置き，その上にフライパンを載 せ，フライパンの中央付近に図 2 のように切り出したガラ スを並べた。

4）ガラスを並べた後，鍋焼きうどん用容器を，並べたガラス が見えるように被せた（図３）。

5) ガスコンロの火をつけ，10分間静置した（このとき，どの 程度ガスを開くかは事前に熱電対を用いてフライパン中央 が $400^{\circ} \mathrm{C}$ になる開き具合を確認し，その開き具合に固定し た)。

6) 摚汼した溶液をアトマイザーに移した。

7）ドラフト内において，ガラスにアトマイザーから塩化スズ 溶液を噴霧した。このときガラス 25 枚に一度にスプレーを するのではなく，全体を 4 分割して $1 / 4$ ずつ噴霧を行った (図 4 )。つまり，噴霧 4 回を 1 セットとなし，これを70セッ

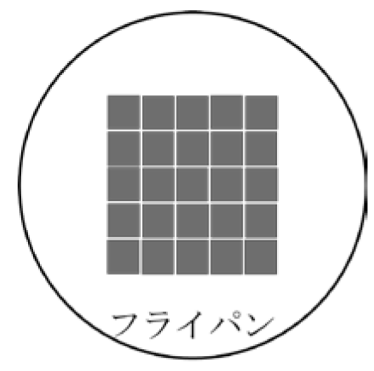

図 2 ガラスの並べ方

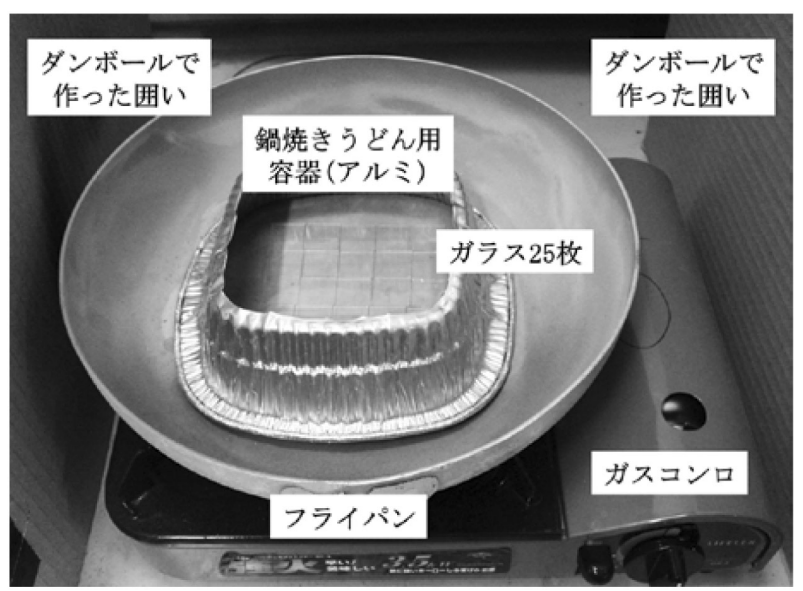

図 3 鍋焼きうどん用容器を被せた様子

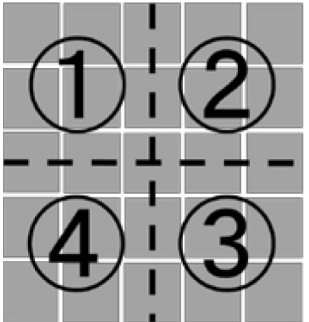

図 4 噴霧の仕方

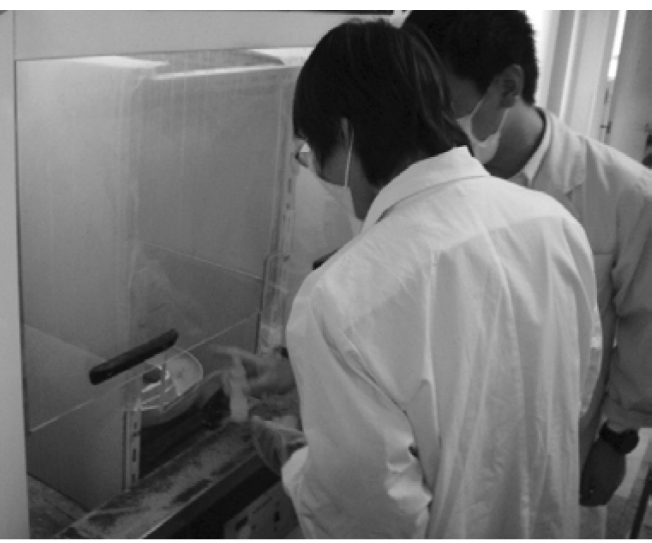

図 5 電気伝導性ガラス製作実験の様子 ( $\mathrm{N}$ 高等学校化学実験室 における授業実践にて)

ト繰り返した。噴霧を行うとガラスの温度が下がるため, ガラスの温度が再び上がるまで，5秒待ってから次のスプ レーを行った。

8) 噴霧終了後, 放冷をして電気伝導性ガラスを回収した（図 $5)$ 。

\section{4. 結 果}

\section{1 手作り電気伝導性ガラスの性能評価}

\subsection{1 膜厚・体積抵抗率測定}

手作り電気伝導性ガラスの性能評価をするために，膜厚と 体積抵抗率の測定を行った。その際に，比較として従来，当 研究室で使用してきた市販品電気伝導性ガラス (AGCファブ リテック(株)製）についても同様に測定を行った。下記にそ の結果を示す (表 1 )。

上記結果より, 市販品と手作り品を比較しても, 膜厚, 体 積抵抗率のどちらにおいても，オーダーがずれるほどの大き な違いは見られなかった。つまり，本研究において開発した 電気伝導性ガラス製作実験は高校の授業で用いる材料として みた場合，市販品と遜色ない性能の電気伝導性ガラスをつく れることがわかった。

4.1 .2 色素増感太陽電池製作後のソーラーシミュレーター における性能評価

上述した手作り電気伝導性ガラス（図６）を用いて製作し た色素増刊太陽電池の性能評価をソーラーシミュレーターを 用いて行った。

開放電圧, 短絡電流, 变換効率, 曲線因子を測定した結果 を以下に示す（図 7, 表 2)。

表 1 市販品と手作り品の物性比較

\begin{tabular}{c|c|c}
\hline & 膜厚〔nm〕 & $\begin{array}{c}\text { 体積抵抗率 } \\
{[\Omega \cdot \mathrm{cm}]}\end{array}$ \\
\hline $\begin{array}{c}\text { 市販品電気 } \\
\text { 伝導性ガラス }\end{array}$ & $1.04 \times 10^{2}$ & $1.06 \times 10^{-3}$ \\
\hline $\begin{array}{c}\text { 手作り電気 } \\
\text { 伝導性ガラス }\end{array}$ & $2.37 \times 10^{2}$ & $4.15 \times 10^{-3}$ \\
\hline
\end{tabular}




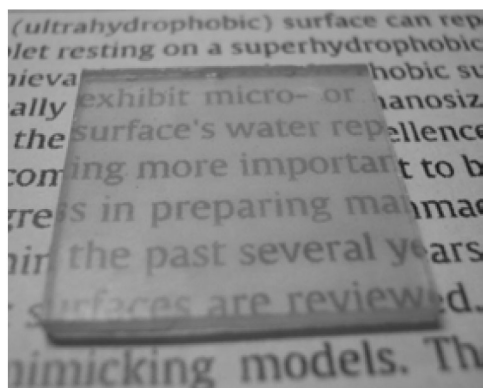

図 6 手作り電気伝導性ガラス

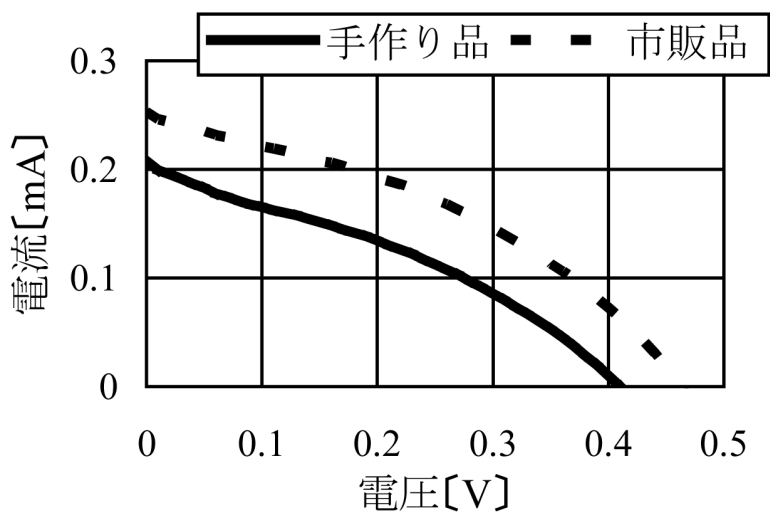

図 7 ソーラーシミュレーターの結果比較

表 2 性能比較表

\begin{tabular}{c|c|c|c|c}
\hline & $\begin{array}{c}\text { 開放電圧 } \\
{[\mathrm{V}]}\end{array}$ & $\begin{array}{c}\text { 短絡電流 } \\
{[\mathrm{mA} 〕}\end{array}$ & 曲線因子 & $\begin{array}{c}\text { 変換効率 } \\
{[\%]}\end{array}$ \\
\hline 市販品データ & 0.46 & 0.25 & 0.39 & 0.013 \\
\hline 手作りデータ & 0.42 & 0.21 & 0.38 & 0.008 \\
\hline
\end{tabular}

測定により得られた電流一電圧曲線から太陽電池の性能を あらわす因子である曲線因子, 最大電力, 変換効率を求めた。 回路を短絡させたとき(電圧が 0 のとき) の電流が短絡電流, 電流が流れていないとき（電流が０のとき）の電圧が開放電 圧である。実際に太陽電池が外部に出力できる電力は, 電流 一電圧曲線上で電流×電圧の值が最大になるときで，これが 最大電力 $P_{M A X}$ となり, この点を最適動作点という。そして, 短 絡電流 $\times$ 開放電圧と最大電力の比は曲線の良好さを示す曲線 因子（fill factor： $f f$ ) となる。曲線因子は

$$
f f=\frac{\text { 最適動作点での電力 }}{(\text { 解放電圧 }) \times(\text { 短絡電流 })}
$$

と表すことができる。曲線因子は最適動作点で囲まれる面積 と, 短絡電流と開放電圧で囲まれる面積の比でもあらわされ る。また太陽電池の変換効率 $\eta(\%)$ は,

$$
\eta=\frac{(\text { 解放電圧 }) \times(\text { 短絡電流 }) \times(\text { 曲線因子 })}{\text { 受け取った太陽光エネルギー }} \times 100
$$

となる。太陽光の単位面積当たりのエネルギーは, 地表付近 での平均である $100 \mathrm{~mW} / \mathrm{cm}^{2}$ として計算した。

ソーラーシミュレーターの結果より, 市販品電気伝導性ガ ラスを用いて製作した色素増感太陽電池の方が良い性能を示 しているが，手作り電気伝導性ガラスを用いて製作した色素
表 3 金額比較

\begin{tabular}{c|c|c}
\hline & $\begin{array}{c}1 \text { 枚 }(2 \mathrm{~cm} \times 2 \mathrm{~cm}) \\
\text { あたりの金額 }\end{array}$ & $\begin{array}{c}1 \text { クラス } \\
\text { あたりの金額 }\end{array}$ \\
\hline $\begin{array}{c}\text { 市販品電気 } \\
\text { 伝導性ガラス }\end{array}$ & 22.0 円 & 7,052 円 \\
\hline $\begin{array}{c}\text { 手作り電気 } \\
\text { 伝導性ガラス }\end{array}$ & 7.95 円 & 2,544 円 \\
\hline 差額 & 14.05 円 & 4,508 円 \\
\hline
\end{tabular}

増感太陽電池の性能も市販品と比べ，大きな違いは見られな かった。また, 当研究室では, 色素増感太陽電池実験におけ る発電確認では電子メロディーを使用しており, その電子メ ロディーは約 $0.8 \mathrm{~V}, 0.1 \mathrm{~mA}$ 程度で発電確認をすることができ る。その電子メロディーを用いて発電確認するために, 手作 り電気伝導性ガラスを用いて製作した色素増感太陽電池では 4 セル直列接続が必要であった。市販品電気伝導性ガラスを 用いて製作した色素増感太陽電池でも，もともと 4 セル直列 接続が必要であるので, 手作り電気伝導性ガラスを用いた色 素増感太陽電池は十分な性能を有していると判断した。これ により，手作り電気伝導性ガラスを用いた色素増感太陽電池 を，高等学校の授業で実験教材として用いることができると 考えた。

\section{2 電気伝導性ガラス製作のコスト}

現在，理科実験の消耗品において年間一人あたりに使うこ とができる金額は341円であるといわれている9)。そこで，教 材開発においては，金額面での検討，つまりコストダウンが ますます重要となってきている。電気伝導性ガラス製作実験 を行うことで電気伝導性ガラスに関するコストがどの程度削 減できたかどうか以下に示す（表 3 ）。

表 3 より，電気伝導性ガラス 1 枚あたり，14.05円削減する ことができ，1クラス (40人) あたり，4,508 円削減すること ができたことがわかる。電気伝導性ガラスは一度購入すれば 何度かは使用できるため，上記の金額は色素増感太陽電池実 験を行うためにかかる初期費用ではあるが，大幅にコストダ ウンすることができたといえる。理科実験の重要性が説かれ はするものの実験予算が厳しい状況にあり，それが一因と なって理科実験がされていない現状もあるため，コストダウ ンを目的としてスタートした研究ではないが，4,058円のコス トダウンができた点は大きく評価できると考えられる。

\section{5. 授業実践}

ここまでの研究結果により, 電気伝導性ガラス製作実験を 開発するという当初の目的は果たすことができ，さらに大幅 なコストダウンをすることができた。これで，材料面からみ た場合には，高等学校の授業において実験教材として用いる ことができる可能性が高くなったが，実際に，授業で活用で きるかどうかは，授業実践を試行し，高校生からの率直な評 価を貴う必要があるといえる。仮に本研究で開発をした電気 伝導性ガラス製作実験の難易度が高く，高校生が行えないと 
なると，教師が事前に生徒の人数分の電気伝導性ガラスを製 作しておかなければならず，教育現場に適した教材を開発し たとは言い難いと考えられる。そこで，本研究において開発 をした電気伝導性ガラス製作実験が高校生にも簡単に行うこ とができ，さらに従来行ってきた色素増感太陽電池実験が高 校生の作った電気伝導性ガラスで成功させることができるか どうか授業実践を行い検証することとした。

\section{1 授業実践の概要}

本研究はSPPにおける実践依頼を受け, “電気伝導性ガラス 製作実験を取り入れた色素増感太陽電池実験”として，出前 授業を行ったものである。

実践日時：2012 年 11 月 5 日（月）

$9: 30 \sim 10: 20$ ( 2 限),

$10: 30 \sim 11: 20$ (3 限) 合計 2 時限分

実践対象：京都府立 $\mathrm{N}$ 高等学校

普通科 1 年生 28 名

実践場所：京都府立 $\mathrm{N}$ 高等学校化学実験室

\section{2 授業実践の内容}

本研究では授業実践として 2 時限分 (100分間) という授業 時間にて電気伝導性ガラス製作実験を取り入れた色素増感太 陽電池実験を行った。実践内容は, 色素増感太陽電池実験に加 え，新たに電気伝導性ガラス製作実験を加えたものである ${ }^{10)} 。$ 大きな流れとしては，(1)負極の作製 (二酸化チタンの塗布，色 素の定着)，(2)正極用電気伝導性ガラスの作製，(3)正極の作製 (黒鉛の塗布)，(4)作製した正極，負極，電解液(イソジン)を 用いてセル作製，(5)電子メロディーを用いた発電確認実験，と いう展開にて授業実践を行った。細かい授業展開については 末尾に付録として示す。

授業終了後，アンケートを取り，実験の成功率，授業に対 する評価をしてもらった。さらに率直な意見・感想を聞くた めにインタビューを行った。

\section{3 授業実践の結果}

付録における授業計画の流れに沿って授業実践を行ったと ころ，どの班も電子メロディーの発電に成功をすることがで きた。つまり，授業時間内で高校生が手作りした電気伝導性 ガラスの性能が色素増感太陽電池を製作するのに十分なもの であり，高校生でも授業時間内に作ることが可能であること がわかった。また，授業後アンケートを，全くあてはまらな い:1，あまりあてはまらない:2，どちらともいえない:3，ま あまああてはまる:4, とてもあてはまる:5，として行ったと ころ，“「色素増感太陽電池」の実験は㧍もしろかった”, “今 回のような，実験を行う授業を今後も授業で行って欲しい”と いう質問項目に対してアンケート結果平均で 4.72，4.50 とい う非常に高い評価を得ることができた。このことから本研究 における電気伝導性ガラス製作まで含めた色素増感太陽電池 実験は，高校生が行っても成功率が非常に高く，さらに高校 生にとっておもしろく，また実験をやりたいと感じさせるこ
とができる実験であったことがわかった。

\section{4 授業実践後の感想}

本研究における授業実践後にインタビューを行ったところ， 色素増感太陽電池実験に関して，以下のような感想を聞くこ とができた。

“実際に自分の手でつくることで，仕組みなどがよく理解で きた”

“自分たちの力でも頭を使って考えれば電気エネルギーを作 れるということを学んだ”

また，電気伝導性ガラス製作についてもインタビューを 行ったところ，以下のような感想を聞くことができた。

“ガラスは無機物で，電気を通さないという考えを180度変 えさせられる出来事でした”

“最先端科学技術が身近に感じた”

インタビューにより，実際に電気伝導性ガラスを製作し，自 らの手で色素増感太陽電池を製作することで，それぞれにお いて，学びや気づき，感動があったことが伺い知ることがで きた。また，その他にも

“太陽光発電のことをもっと知りたくなった”

“今，エネルギー問題が大変なのでこれを利用してエネル ギーを作れたらいいなと感じた”

“(将来について) 大学生になったら，自分の好きなことを じっくり研究できるので楽しそうだと感じた” などという感想もあり，エネルギー教育やキャリア教育とし ても有用である可能性があることが示唆された。

\section{6. おわりに}

本研究では高校生自身が授業時間内に電気伝導性ガラスを 製作し，その電気伝導性ガラスを用いて色素増感太陽電池を 製作するという非常にチャレンジングな授業実践に取り組み, 成功を収めることができた。大学の学生実験のレベルでも, 電 気伝導性ガラス製作はあまり多くは実施されていないことか ら判断すると, 高等学校の 2 時限分 (100分間) の授業のなか で電気伝導性ガラスを製作を実践した事例は多くはないと考 えられる。しかも, 色素増感太陽電池を製作するための電気 伝導性ガラスの製作なので，導電性が確認できるだけでなく， 高校生が色素増感太陽電池を製作しても利用に耐えるものを つくる必要があったので，極めて困難な課題であった。

また, 従前より, 色素増感太陽電池の生徒実験では, 電子 メロディーを鳴らすことだけでなく, 色素増感太陽電池搭載 型の模型自動車の生徒実験が期待されてきた。当研究室でも, 市販の電気伝導性ガラスを用いての実験教材の開発に成功し ているが，これにより，生徒が自作する電気伝導性ガラスを 用いた実験教材の開発も急がれることとなった。

最後に, 東日本大震災が起き, 色素増感太陽電池の生徒実 験において, もっとも重要な実験材料の電気伝導性ガラスの 入手が困難になった。もともと, 色素増感太陽電池の生徒実 験が，高校の教育現場で広がっていくためには，電気伝導性 ガラスを高校生が自作できることが必要であると考えていた 
ので，“ピンチはチャンス”という言葉があるように，実験教 材の研究開発のチャンスとなった。これからも本研究のよう な，生徒にとっておもしろく，もっと実験をやりたいと感じ させることができる実験教材を多く開発していきたいと筆者 らは考えている。

\section{文 献：References}

1) Ministry of Education, Culture, Sports, Science and Technology: Chuugakkou gakushuu shidouyouryou kaisetsu rikahenn (Ministry of Education, Culture, Sports, Science and Technology)，(2008）：文部科学省, 中学校学習指導要領解説理科編 (文部科学省), (2008)

2) Miura, N. et al.: Koutougakkou rikayou butsuri kiso (Tokyoshoseki), pp. 228-229(2011)：三浦登ら, 高等学校 理科用物理基礎(東京書籍), pp. 228-229(2011)

3) Nakabayashi, K.; Koyae, H.; Yokoyama, I.: Journal of Research in Science Education, 52 (3), 121-128(2012)：中林健一，小八 重宏樹, 横山育生, 理科教育学研究, 52(3), 121-128 (2012)

4) Miyamoto. N.; Yamamoto, K.: Kagaku to kyouiku, 54 (3), 172-
173(2006)：宮本憲武，山本勝博，化学と教育，54(3), $172-173(2006)$

5) Kawamura, Y.: Idenn, 59 (6), 15-19(2005)：川村康文，遺 伝，59(6)，15-19(2005)

6) Oda, Y. et al.: Journal of Energy and Environmental Education, 3 (1)，71-77(2008)：小田善治ら，エネルギー環境教育研 究，3(1)，71-77(2008)

7) Kawamura, Y. et al.: Journal of the Physics Education Society of Japan, 58(2), 84-88(2010)：川村康文ら，物理教育，58 (2) , 84-88(2010)

8) Sawada, Y. et al:: Toumeidoudennmaku no shinntennkai II, (Shiemushishuppann), pp. 113-121(2007)：澤田豊ら，透 明導電膜の新展開 II，(シーエムシー出版)， pp. 113-121 (2007)

9) Japan Science and Technology Agency, (2008)：(独)科 学技術振興機構, http://www.jst.go.jp/pr/announce/ 20080912/index.html(2013年1月7日確認) (2008)

10) Kawamura, Y.; Tayama, T.; Kodama, A.: J. Jpn. Inst. Energy, 91(6), 503-507 (2012)：川村康文，田山朋子，兒玉明典, 日エネ誌，91(6)，503-507(2012) 
付録 授業計画

【 1 時限目】

\begin{tabular}{|c|c|c|c|}
\hline 段階 & 学習内容 & 教師の活動 & 生徒の活動 \\
\hline $\begin{array}{l}\text { 挨拶·点呼 } \\
(2 \text { 分 })\end{array}$ & & $\begin{array}{l}\text { ·挨拶をする } \\
\text { ・出席確認をする }\end{array}$ & ·挨拶をする \\
\hline $\begin{array}{l}\text { 導入 } \\
\text { (3 分) }\end{array}$ & $\begin{array}{l}\text { 太陽電池 } \\
\text { について } \\
\text { ( } 3 \text { 分) }\end{array}$ & $\begin{array}{l}\text { 「発問」「みなさんのまわりで太陽電池はどこにありますか? } \\
\text { ·本時で製作する太陽電池の種類を紹介し, どの種類の太陽 } \\
\text { 電池を製作するのかを理解させる }\end{array}$ & $\begin{array}{l}\text { 「予想される生徒の回答」 } \\
\text { 家の屋根, 携帯など } \\
\text { ・説明を聞く }\end{array}$ \\
\hline $\begin{array}{l}\text { 展開 I } \\
(5 \text { 分) }\end{array}$ & $\begin{array}{l}\text { テスター } \\
\text { の使い方 } \\
\text { ( } 5 \text { 分) }\end{array}$ & $\begin{array}{l}\text { ·電気伝導性ガラスの説明をする } \\
\text { 「発問」「実は電気伝導性ガラスは, 身の回りに溢れています。 } \\
\text { どこで使われているでしょう？」 } \\
\text { •テスターの説明をし, テスターを用いて電気伝導性ガラス } \\
\text { の電気伝導面を確認させる }\end{array}$ & $\begin{array}{l}\text { ·説明を聞く } \\
\text { 「予想される生徒の回答」 } \\
\text { 空ガラス, 液晶など } \\
\text { •説明を聞く } \\
\text { •テスターを用いて電気伝導面の確認をす } \\
\text { る }\end{array}$ \\
\hline $\begin{array}{l}\text { 展開 II } \\
\text { (20 分) }\end{array}$ & $\begin{array}{l}\text { 負極の製 } \\
\text { 作 (20 分) }\end{array}$ & 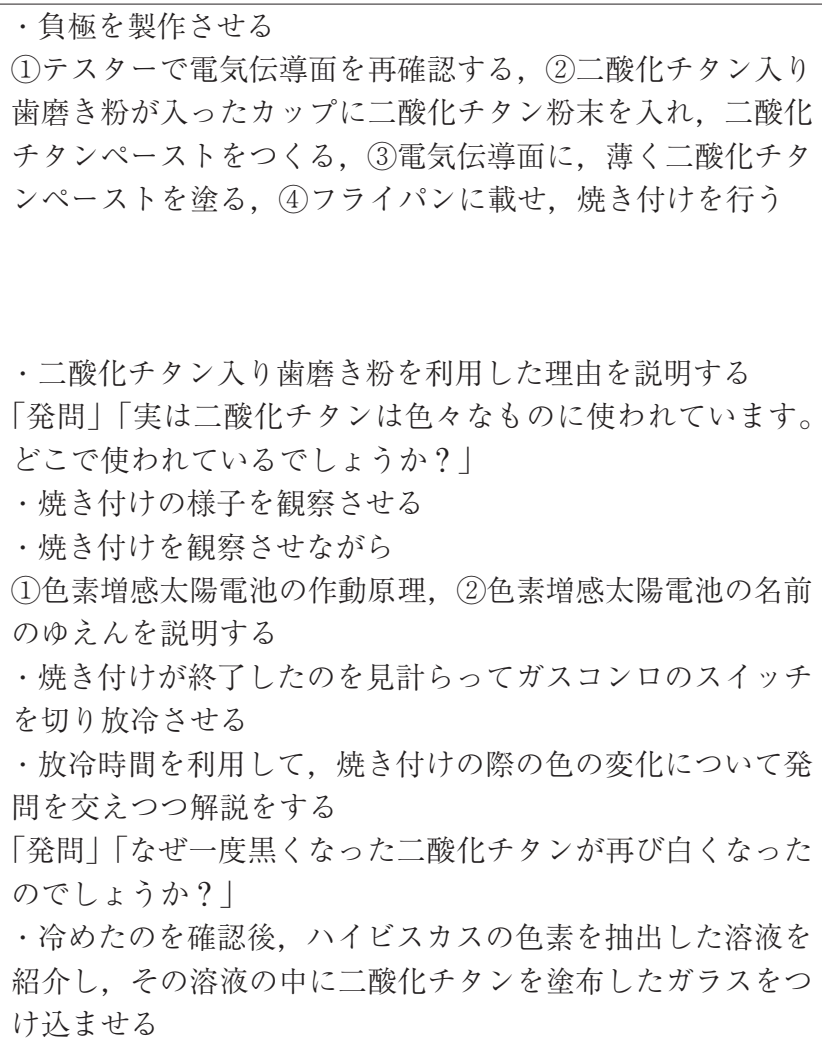 & 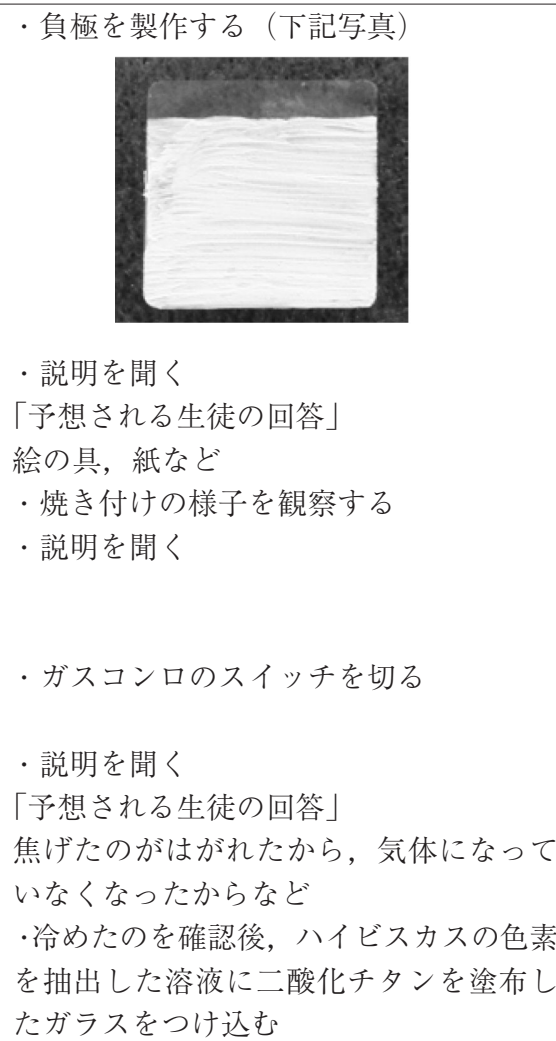 \\
\hline $\begin{array}{l}\text { 展開 III } \\
(20 \text { 分) }\end{array}$ & $\begin{array}{l}\text { 正極用電 } \\
\text { 気伝導性 } \\
\text { ガラスの } \\
\text { 製作 } \\
\text { (20 分) }\end{array}$ & 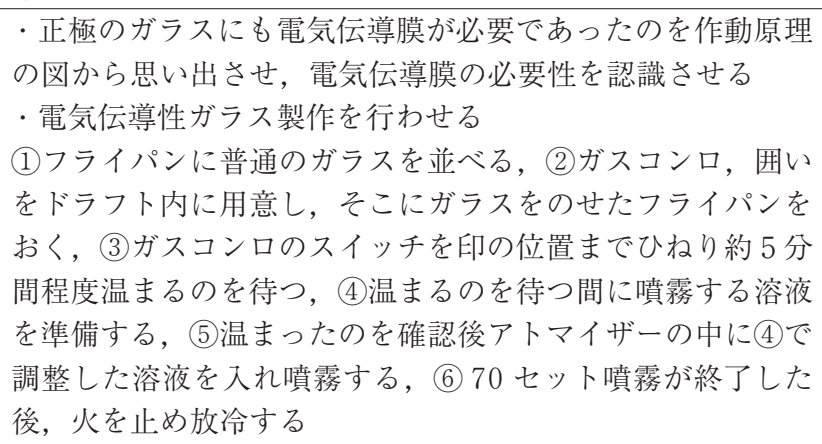 & $\begin{array}{l}\text { ・説明を聞く } \\
\text { ・電気伝導性ガラス製作を行う } \\
\text { (下記写真) }\end{array}$ \\
\hline
\end{tabular}


【2 時限目】

\begin{tabular}{|c|c|c|c|}
\hline 段階 & 学習内容 & 教師の活動 & 生徒の活動 \\
\hline $\begin{array}{l}\text { 展開 IV } \\
(5 \text { 分) }\end{array}$ & $\begin{array}{l}\text { 正極の製 } \\
\text { 作 } \\
\text { ( } 5 \text { 分) }\end{array}$ & $\begin{array}{l}\text { 展開 III で製作した電気伝導性ガラスを用いて正極を製作さ } \\
\text { せる } \\
\text { (1)電気伝導面をテスターで確認をする，(2)電気伝導面に鉛筆 } \\
\text { で炭素を塗布する }\end{array}$ & ・正極を製作する \\
\hline $\begin{array}{l}\text { 展開 V } \\
\text { (10 分) }\end{array}$ & $\begin{array}{l}\text { セル製作 } \\
\text { (10 分) }\end{array}$ & $\begin{array}{l}\text { ·1 } 1 \text { 人つ, セルを製作させる } \\
\text { 1)ハイビスカス溶液から負極を取り出し, キムワイプでかる } \\
\text { く拭く, (2)負極にイソジンを } 3 \sim 4 \text { 滴垂らし, 正極とイソジ } \\
\text { ンをサンドイッチする形でセルを組み黒クリップで固定する } \\
\text { 「発問」「魚型しょうゆさしの中に入っている茶色の液体はな } \\
\text { んでしょうか? }\end{array}$ & $\begin{array}{l}\cdot 1 \text { 人 } 1 \text { つ, セル製作をする (下記写真) } \\
\text { ·発問に答える } \\
\text { 「予想される回答」 } \\
\text { 㽜油，イソジンなど }\end{array}$ \\
\hline $\begin{array}{l}\text { 展開VI } \\
\text { (20 分) }\end{array}$ & $\begin{array}{l}\text { 発電確認 } \\
\text { (20 分) }\end{array}$ & $\begin{array}{l}\text { ·班員と協力をして発電確認をさせる } \\
\text { (1) } 3 \text { 〜 } 5 \text { セ程度, 直列接続する, (2)十とーを間違えないよ } \\
\text { う電子メロディーを接続する, (3)LEDやハロゲンライトなど } \\
\text { 光源を当て発電確認をする }\end{array}$ & ·班員と協力して発電確認をする \\
\hline $\begin{array}{l}\text { まとめ } \\
\text { (15 分) }\end{array}$ & $\begin{array}{l}\text { まとめ } \\
\text { (15 分) }\end{array}$ & $\begin{array}{l}\text { ·色素増感太陽電池の特徵 (長所, 短所)について説明をする } \\
\text { ・エネルギー利用について話をする } \\
\text { •アンケートを行わせる }\end{array}$ & $\begin{array}{l}\text { ·説明を聞く } \\
\text { ·説明を聞く } \\
\text { •アンケートに回答する }\end{array}$ \\
\hline
\end{tabular}

